\title{
Kompetensi Widyaiswara di Era Digital dan Media Sosial
}

\author{
Hasan Ashari ${ }^{1}$, Bambang Sancoko ${ }^{2}$ \\ Hasanashari.pusdiklatap@gmail.com ${ }^{1}$, bambangcoko@gmail.com $^{2}$ \\ Pusdiklat Anggaran dan Perbendaharaan \\ Badan Pendidikan dan Pelatihan Keuangan \\ Kementerian Keuangan ${ }^{12}$
}

\begin{abstract}
Abstrak
Tranformasi digital menjadi perhatian pemerintah dengan dikembangkan layanan pemerintah berbasis teknologi dan media sosial. Demikian pula di bidang pelatihan/pengembangan komptensi pegawai. Widyaiswara mempunya peran penting dalam pengelolaan pelatihan. Widyaiswara dituntut melakukan transformasi sesuai perkembangan teknologi digital dan media sosial. Penelitian ini bertujuan mendeskripsikan kompetensi widyaiswara, media digital dan sosial yang tepat, serta pola kolaborasi lembaga pelatihan di era digital. Penelitian ini adalah deskriptif dengan metode studi literatur. Berdasarkan hasil pembahasan, minimal ada lima kompetensi yang harus dimiliki widyaiswara yaitu informasi dan Literasi data, Komunikasi dan kolaborasi, kemampuan menciptakan konten digital, Keamanan dan kemampuan memecahkan dan mengatasi persoalan secara teknis. Widyaiswara harus mampu memilih media digital dan media sosial yang tepat. Kolaborasi penggunaan media digital dan media sosial oleh lembaga pelatihan dapat meningkatkan efisiensi bahkan sumber penerimaan negara. Widyaiswara agile adalah karakter yang dapat menjawab tantangan di era digital. Beberapa hal yang direkomendasikan adalah widyaiswara harus mengembangkan kompetensi digital, perlunya kode etik bagi widyaiswara di era digital dan dibuat regulasi yang memungkinkan penerimaan negara dari penggunaan media sosial.
\end{abstract}

Kata kunci: widyaiswara, media sosial, era digital

\begin{abstract}
Digital transformation is the government's main concern which represented by technology and social media-based services. This concept also adapted to civil servant development and training programs which becomes the main task for Widyaiswara. This study aims to describe the widyaiswara's competencies, appropriate digital and social media, and the collaborative patterns of training institutions in the digital era. The research is descriptive, and analyze using the literature review method. The result shows us five major competencies which are important, namely: information and data literacy, communication and collaboration, digital content creation, digital security, and technical problem-solving. The user also needs to choose the right digital and social media platform since the usage of those by training institution tend to increase efficiency and, moreover, government income sources. There are several recommendations for widyaiswara from this research, such as: the need to increase digital competency, the need of ethical code in a digital era, and the need for regulation that possible government to get revenue from social media.
\end{abstract}

Keyword: widyaiswara, social media, digital era 
Jurnal PINUS: Jurnal Penelitian Inovasi Pembelajaran, 7 (1), 2021, Hasan Ashari, Bambang Sancoko

\section{PENDAHULUAN}

Salah Upaya transformasi digital menjadi perhatian serius pemerintah dengan digulirkannya program tol langit sejak Oktober 2019. Untuk membawa Indoseia menuju masa depan, transformasi digital merupakan solusi cepat dan strategis. Meskipun demikian harus tetap memperhatikan terciptanya kedaulatan dan kemandirian digital. Hal ini disampiakan oleh Presiden Joko Widodo pada acara acara peluncuran program konektivitas digital 2021 (Kompas, 2021)

Pengguna internet pada quartal II tahun 2020 di Indonesia adalah 196,71 juta orang dari 266,91 juta populasi atau $73,7 \%$ (Asosiasi Penyelenggara Jasa Internet Indonesia, 2020). Di era pandemi tentu jumlah penetrasi pengguna internet semakin meningkat. Pola kerja WFH dan rapat daring menjadi budaya baru dalam organisasi baik sektor publik maupun private.

Akselerasi pelaksanaan $e$ government menemukan momentum yang tepat. Layanan pemerintah berbasis digital menjadi tuntutan yang tidak dapat dihindari. Layanan bidang pelatihan dan pengembangan pegawai tidak luput dari akselerasi tersebut. Transformasi digital dilakukan dengan mengubah laman lembaga/badan pelatihan pemerintah yang semula sebagi penyedia informasi menjadi knowledge management system (KMS). KMS menjadi sarana yang menyediakan berbagai kebutuhan pengembangan kompetensi pegawai. Pengembangan KMS di instansi pemerintah dipelopori oleh Kementerian Keuangan sejak tahun 2018 dengan diterbitkannya Keputusan Menteri Keuangan No. 924/KMK.011/2018 tentang Kementerian Keuangan Corporate University.

Bersamaan dengan proses transformasi digital berkembang juga media digital. Teknologi digital yang berkembang didukung oleh fitur khusus media digital yang memungkinkan fleksibilitas terfokus pada media, distribusi konten, interaksi pengguna dan konten yang dapat dikendalikan pengguna (Melissa, 2010). Media digital yang berkembang berbasis internet menghilangkan sekat wilayah dan waktu. Kapan saja dan dimana saja manusia dapat melakukan aktivitas untuk memenuhi kebutuhannya.

Perkembangan yang sangat menonjol di dunia digital adalah penggunaan media sosial. Pengguna media sosial mendominasi penggunaan internet di Indonesia yaitu hampir 90\% (Hermawansyah \& Pratama, 2021). Media sosial sebagai sarana dapat memberikan dampak posistif ataupun negatif. Hal ini tergantung pada pemahaman dan perilaku pengguna. Media sosial dapat menyebarkan informasi apapun dengan cepat dan luas (Anwar \& Rusmana, 2017).

Pengguna internet di Indonesia lebih dominan mengunjungi laman hiburan dibandingkan dengan konten pendidikan. Berdasarkan survey APJII (2020) 52,8\% responden tidak pernah mengunjungi laman pendidikan. Demikian pulan penggunan medis sosial lebih dominan digunakan mengunjungi konten hiburan dibandingkan pendidikan. 
Jurnal PINUS: Jurnal Penelitian Inovasi Pembelajaran, 7 (1), 2021, Hasan Ashari, Bambang Sancoko

Keberadaan layanan pelatihan secara digital oleh instansi pemerintah dan media sosial tentu tidak bisa diposisikan sebagai kompetitor antara satu dan lainnya. Justru kedua media ini harus dapat saling melengkapi dan kolaborasi dalam menyediakan konten dan metode sesuai kebutuhan user, dalam hal ini adalah para ASN. Dalam pelatihan di lingkungan kementerian/lembaga penyusunan metode dan konten pelatihan menjadi tugas widyaiswara.

Tugas widyaiswara sebelum era digital dilakukan secara konvensional. Ketika memasuki era digital, widyaiswara harus mampu melakukan transformasi digital agar dapat memberikan kontribusi dalam pengembangan kompetensi para pengguna. Pada paper ini penulis membahas aspek-aspek yang harus dimiliki oleh widyaiswara untuk eksistensi di era digital dan media sosial.

Transformasi digital dengan berbagai perkembangan di dunia digital dan media sosial adalah tantangan. Widyaiswara adalah sosok yang penting dalam menyiapkan sumber daya manusia. Widyaiswara harus mampu melakukan transformasi dalam menghadapi era digital dan media sosial. Permasalahan yang harus diantisipasi adalah apa yang harus dipersiapkan oleh widyaiswara memasuki era digital dan media sosial. Dalam paper ini, penulis akan membahas permasalahan sebagai berikut:

1. Apakah kompentensi yang dibutuhkan oleh Widyaiswara di era digital dan media sosial?

2. Apakah jenis media sosial yang dapat di jadikan sarana pengembangan kompetensi widyaiswara dan pengguna?

3. Bagaimana kolaborasi Knowlegde Management System dengan Media Sosial sebagai sarana pengembangan kompetensi pengguna?

Tujuan dari penulisan paper ini adalah untuk mengetahui:

1. kompentensi yang dibutuhkan oleh Widyaiswara di era digital dan media sosial.

2. jenis media sosial yang dapat dijadikan sarana pengembangan kompetensi widyaisara dan pengguna.

3. Bentuk kolaburasi Knowlegde Management System dengan Media Sosial sebagai sarana pengembangan kompetensi pengguna

\section{TINJAUAN LITERATUR}

Tugas dan Fungsi Widyaiswara

Widyaiswara berdasarkan Peraturan Menteri PAN-RB Nomor 22 Tahun 2014 adalah Pegawai Negeri Sipil yang diangkat sebagai pejabat fungsional dengan tugas, tanggung jawab, wewenang, dan hak untuk melakukan kegiatan:

1. Mendidik, mengajar dan melatih PNS

2. Evaluasi dan Pengembangan pendidikan dan pelatihan pada Lembaga Pendidikan dan Pelatihan Pemerintah.

Tugas pokok Widyaiswara adalah dua hal sebagaimana dalam definisi di atas. Yang dimaksud mendidik, mengajar dan melatih adalah proses belajar mengajar dalam pendidikan dan pelatihan yang diselenggarakan baik secara klasikal dan/atau non klasikal. Berdasarkan 
Jurnal PINUS: Jurnal Penelitian Inovasi Pembelajaran, 7 (1), 2021, Hasan Ashari, Bambang Sancoko

Peraturan Kepala LAN RI Nomor 26 Tahun 2015 kegiatan widyaiswara yang akan dihitung angka kredit. Unsur angka kredit adalah utama dan penunjang. Kegiatan unsur utama yang dilaksanakan adalah mengikuti pendidikan dan pelatihan, melaksanakan dikjartih ASN dan Non ASN, Evaluasi dan Pengembangan diklat, Pengembangan Profesi.

Pelaksanaan tugas Widyaiswara disesuaikan dengan spesialisasi berasarkan pada rumpun keilmuan tertentu sesuai latar belakang pendidikan dan/atau pengalaman kerja. Hal ini harus didukung dengan kompetensi yang sesuai dengan bidang spesialisasi. Kompetensi widyaiswara adalah pemilikan pengetahuan, keterampilan, dan kemampuan. Kompetensi yang dituntut oleh Jabatan Fungsional Widyaiswara adalah pengelolaan pembelajaran, substansi, kepribadian, dan sosial.

Standar kompetensi widyaiswara berdasarkan Perkalan Nomor 5 Tahun 2008 adalah kemampuan minimal yang secara umum dimiliki dalam pelaksanaan tugas, tanggung jawab dan wewenangnya untuk mendidk, mengajar dan melatih Pegawai Negeri Sipil. Standar kompetensi Widyaiswara ada empat yaitu kompetensi:

a. pengelolaan pembelajaran adalah kemampuan merencanakan, menyusun, melaksanakan, dan mengevaluasi pembelajaran

b. kepribadian adalah kemampuan terkait tingkah laku dalam melaksanakan tugas jabatan sehingga dapat diamati dan dijadikan teladan bagi peserta pendidikan dan pelatihan c. sosial adalah kemampuan untuk membangun hubungan dengan lingkungan kerjanya

d. substantif adalah kemampuan terkait bidang keilmuan dan keterampilan dalam mata Diklat yang diajarkan.

Berdasarkan Peraturan Bersama Kepala LAN dan Kepala BKN Nomor 1 Tahun 2015 dan Nomor 8 Tahun 2015 tugas yang dapat dilaksanakan widyaiswara adalah:

a. Pelaksanaan mendidik, mengajar dan melatih

1) Persiapan

a) Menyusun Bahan Pendidikan dan Pelatihan (Bahan Tayang, Bahan Ajar, Bahan Peraga serta GBPP/RBPMD dan SAP/RP)

b) Menyusun Soal/Materi Ujian Pendidikan dan pelatihan

2) Pelaksanaan

a) Tatap Muka Pendidikan dan Pelatihan (PNS)

b) Tatap Muka Pendidikan dan Pelatihan $t$ (Non ASN)

c) Pembimbingan

d) Pendampingan Orientasi Lapangan / PKL / Benchmarking

e) Pendampingan Proyek Perubahan / Penulisan Kertas Kerja

f) Memeriksa Hasil Ujian Pendidikan dan pelatihan

g) Coaching Proses Penyelenggaraan Pendidikan dan pelatihan

b. Evaluasi Dan Pengembangan Pendidikan dan Pelatihan

1) Evaluasi Pendidikan dan Pelatihan 
Jurnal PINUS: Jurnal Penelitian Inovasi Pembelajaran, 7 (1), 2021, Hasan Ashari, Bambang Sancoko

a) Terlibat dalam evaluasi penyelenggaraan Pendidikan dan Pelatihan di instansi

b) terlibat dalam evaluasi kinerja widyaiswara

2) Pengembangan Pendidikan dan Pelatihan

a) Terlibat Analisis Kebutuhan Pendidikan dan Pelatihan

b) Terlibat Penyusunan Kurikulum Pendidikan dan Pelatihan

c) Terlibat Penyusunan Modul Pendidikan dan Pelatihan

c. Pengembangan Profesi

1) Membuat Karya Ilmiah/Karya Tulis sesuai Spesialisasi Keahliannya dan Lingkup Pendidikan dan pelatihan dalam bentuk buku, non buku dan makalah dalam pertemuan ilmiah

2) Penemuan Inovasi Yang Dipatenkan dan Telah Masuk Daftar Paten Sesuai Bidang Spesialisasi Keahliannya

3) Penyusunan Buku Pedoman / Ketentuan Pelaksanaan / Ketentuan Teknis Di Bidang Kediklatan

4) Pelaksanaan Orasi Ilmiah sesuai spesialisasinya.

\section{Dunia digital dan Media Sosial}

Dunia digital pada paper ini penulis interprestasikan era digital. Era digital ditandai dengan semakin berkembangnya teknologi digital. Tekonologi digital digunakan untuk menunjang perkembangan industri. Dengan berbagai perkembangan teknologi digital mendorong terjadinya revolusi industri dan sampai saat ini sudah mencapai revolusi industri 4.0.

Revoulsi industri 4.0 ditopang setidaknya dengan sembilan pilar yang menjadi ciri perkembangan teknologi digital pada era ini (Vaidya et al., 2018). Sembilan pilar tersebut adalah:

a. Analisis Big Data yaitu kemampuan mengolah data dalam jumlah yang besar baik yang terstruktur maupun tidak tersetruktur

b. Robot Otonom yaitu penggunaan teknologi secara otomatis dalam mengatur berbagai kebutuhan sebagaimana robot.

c. Teknologi Simulasi yaitu simulasi proses pekerjaan dari waktu ke waktu untuk memastikan proses kerja sesuai dengan kebutuhan.

d. Integrasi Sistem Horisontal dan Vertikal yaitu intergrasi antar sub sistem agar dapat berjalan sesuai dengan fungsi.

e. Industri Berbasis Internet of Things (IoT) yaitu kemampuan teknologi untuk mentransfer data baik melalui jaringan maupun tidak tanpa campur tangan manusia.

f. Keamanan Siber yaitu perlindungan terhadap data dari serangan.

g. Teknologi Informasi berbasis Cloud yaitu pusat pengolahan data berbasis internet dengan memberikan hak akses pada pengguna sesuai dengan kewenangannya.

h. Manufaktur Aditif yaitu penambahan komponen tertentu dalam produksi sehingga dapat menampilkan hasil produksi secara riil dalam bentuk 3D 
Jurnal PINUS: Jurnal Penelitian Inovasi Pembelajaran, 7 (1), 2021, Hasan Ashari, Bambang Sancoko

i. Teknologi Augmented Reality yaitu penggabungan teknologi secara riil time dengan dunia nyata.

Revolusi Industri 4.0 dengan perkembangan teknologi digital tidak hanya membawa perubahan signifikan dalam proses produksi di dunia industri tetapi di semua aspek kehidupan termasuk layanan publik oleh pemerintah. Era industri 4.0 menciptakan aktivitas perekonomian dan layanan lainnya berbasis inovasi dengan backbound utama pengetahuan, data dan IoT (Morrar \& Arman, 2017).

Teknologi digital meningkatkan optimalisasi waktu dan biaya dalam menghasilkan produk barang atau jasa. Di sektor publik, hal ini berpengaruh pada tuntutan masyarakat untuk mendapatkan layanan yang lebih cepat dan tepat. Tuntutan ini yang megharuskan pemerintah melakukan transformasi layanan dari basis manual menjadi layanan berbasis digital. Dalam era Revolusi Industri 4.0 pemerintah beserta jajaran birokrasi harus dapat beradaptasi dengan sistem yang berkembang di era industri 4.0 agar bisa bertahan dan mendapatkan kepercayaan publik (Schwab, 2016).

Langkah digitalisasi layanan public dilakukan dengan e-government sebagai jawaban untuk adaptasi di era industri 4.0. E-government adalah penggunaan teknologi informasi oleh pemerintah dalam menjalankan layanan publik (Rokhman, 2011). Dengan adanya E-Goverment membuat sistem layanan pemerintahan lebih meningkatkan tingkat aksesibilitas dan partisipasi masyarakat. Dengan e-government, pemerintah mampu melayani pemangku kepentingan secara digital, warga secara lebih efektif berperan dalam efisiensi layanan publik. (Isagah \& Wimmer, 2017). Pemerintah bersungguh-sungguh dalam program $E$ Government dengan diterbitkannya Inpres Nomor 3 Tahun 2003.

Menurut Indrajit,

(2006), implementasi e-government diantaranya:

a. Pemerintah kepada masyarakat (G2C) yaitu bagaimana pemerintah memberikan layanan dasar dan penyampain informasi kepada masyarakat;

b. Pemerintah kepada komunitas bisnis (G2B) yaitu bagaimana pemerintah menjalin hubungan dengan komunitas bisnis. Hal ini dilakukan untuk perizinan usaha, perpajakan dan lain sebagainya;

c. Pemerintah kepada pegawai (G2E) yaitu bentuk layanan pemerintah kepada pegawai pemerintah;

d. Pemerintah kepada pemerintah lain (G2G) yaitu bagaimana hubungan antar tingkat pemerintahan serta antar pemerintah dengan negara lain dalam hubungan internasional.

Dalam layanan G2E, pemerintah melalui lembaga pendidikan dan pelatihan memanfaatkan teknologi digital dalam rangka pengembanan kompetensi pegawai. Pemanfaatan teknologi digital dilakukan dengan mengembangkan knowledge management system (KMS) yang berbasis teknologi digital. Lembaga pelatihan pemerintah yang membangun KMS berbasis digital dipelopori oleh Kementerian Keuangan melalui Badan Pendidikan dan Pelatihan Keuangan 
Jurnal PINUS: Jurnal Penelitian Inovasi Pembelajaran, 7 (1), 2021, Hasan Ashari, Bambang Sancoko

dengan Kemenkeu Corpu (Corporate di unduh dari platfrom mobile baik yang

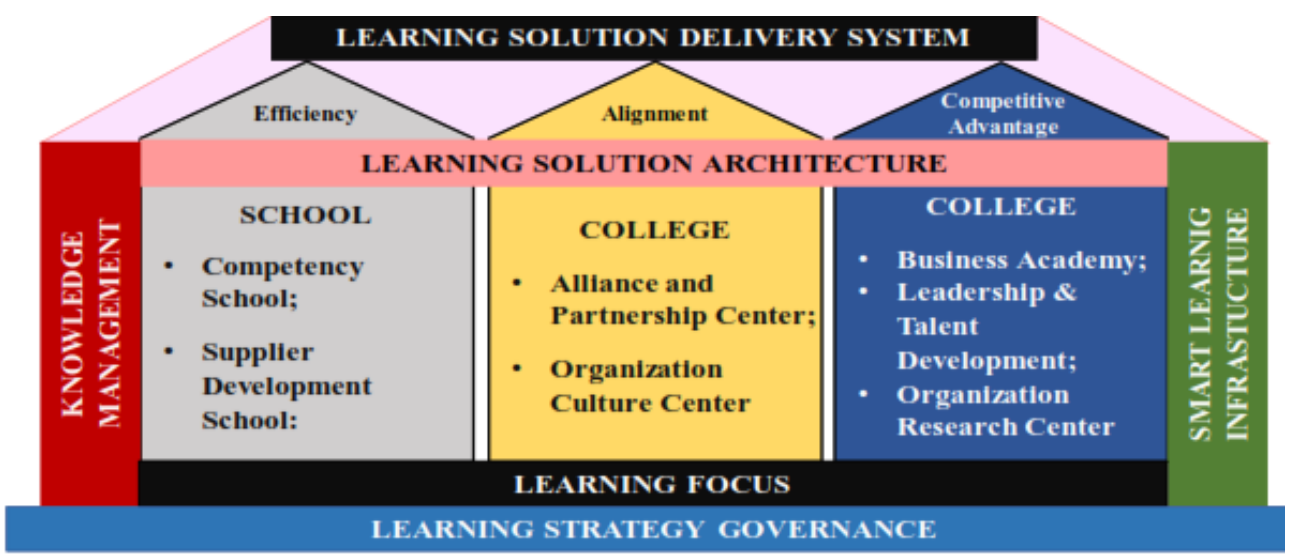

Gambar 1. Infrastruktur Kementerian Keuangan Corporate University

University).

Model Kemenkeu Corporate University diatur dalam KMK No. 924/KMK.011/2018 sebagaimana Gambar 1 Kemenkeu Corpu dibentuk diawali dengan penyusunan strategi pembelajaran dalam tata kelola pemerintahan yang baik (learning strategy governance). Selanjutnya pembelajaran difokuskan dalam tiga hal (learning focus) yaitu school, collage, dan academy. Dua pilar yaitu smart learning infrastructure dan knowledge management mengapit ketiga fokus pembelajaran. Pengelolaan knowledge management yang efektif dan efisien berbasis smart learning infrastructure menentukan kualitas school, collage, dan academy.

Pengelolaan KMS dilakukan dengan infrastruktur berbasis digital dengan menggunakan Learning Management System (LMS) . Bentuk teknologi digital yang digunakan berbasis web yaitu http://klc.kemenkeu.go.id dan mobile. Dengan tagline belajar dari mana saja dan kapan saja, aplikasi mobile dapat berbasis android maupin ios. Langkah kemenkeu Corpu diikuti oleh kementarian/lembaga lainnya untuk menyediakan layanan pengembangan pegawai dengan menggunakan teknologi digital.

Model pendidikan dan pelatihan yang disediakan jika merujuk pada Kemenkeu Corpu berupa pembelajaran secara elektronik (E-learning), pembelajaran terpadu antara elektronik dan klasikal (Blended learning), pemecahan masalah (Problem Solving), Pembelajaran dengan tindakan (Action Learning), klasikal (Class Learning), pembelajran di tempat kerja (On The Job Trainning), Culture Change, Internship, KOmunitas para praktisi (Community Of Practice), dan sebagainya (Fauziah \& Prasetyo, 2019). Dengan model Kemenkeu Corpu yang paling utama adalah bagaimana menciptakan dan mentransfer pengetahuan melalui proses belajar yang dinamis. Maka diperlukan program pelatihan yang tepat untuk mengisi KMS dalam Learning Management System. 
Jurnal PINUS: Jurnal Penelitian Inovasi Pembelajaran, 7 (1), 2021, Hasan Ashari, Bambang Sancoko

Mekanisme pengelolaan

Knowledge Management diatur dalam PMK Nomor 226/PMK.011/2019. Proses

Manajemen Pengetahuan meliputi identifikasi, dokumentasi, pengorganisasian, penyebarluasan, penerapan dan pemantauan. Hal yang terkait langsung dengan proses penyiapan konten digital dan peran widyaiswara yang akan di gunakan di LMS adalah identifikasi dan dokumentasi. Tahap identifikasi dilakukan untuk menentukan Pengetahuan yang akan didokumentasikan sebagai Aset Intelektual. Dokumentasi merupakan kegiatan pendokumentasian pengetahuan (knowledge capture) untuk menghasilkan aset Intelektual yang dilakukan melalui metode diantaranya wawancara, pengamatan, diskusi kelompok terarah dan/atau komunitas belajar (community of practices). Aset Intelektual hasil dokumentasi di tuangkan dalam bentuk audio, visual dan/atau audiovisual. Di beberapa lembaga pelatihan aset intelektual juga dapat berbentuk naskah/tulisan seperti modul, bahan ajar dan lain-lain.

Agar tujuan untuk peningkatan kompetensi tercapai diperlukan konten, metode penyampaian dan sarana yang tepat. Konten yang sesuai dengan kebutuhan objek pengguna, metode penyampaian yang kreatif dan dinamis serta sarana teknologi yang cepat dan handal. Hal ini menjadi syarat yang harus dipenuhi untuk menunjang proses layanan pengembangan kompetensi di era digital.

Media sosial menurut Gohar F. Khan dalam buku Memaksimalkan
Penggunaan Media Sosial Dalam Lembaga Pemerintah yang diterbitkan oleh Ditjen Informasi Dan Komunikasi Publik Kementerian Komunikasi Dan Informatika Republik Indonesia, (2018) menyatakan media sosial adalah media bagi para pengguna untuk membuat dan berbagi konten dengan tujuan yang beragam seperti informasi, edukasi, kritik, sindiran dan sebagainya dengan menggunakan platform berbasis internet kepada pihak lain yang lebih banyak lagi. Berbagai jenis media sosial banyak disediakan penyedia layanan di internet. Sebuah platform dikategorikan menjadi media sosial adalah berbasis pengguna, sangat interaktif, pengguna sebagai pembuat konten, bebas menentukan pengaturan akun, hubungan antar pengguna menentukan terbentuknya komunitas dan peluang koneksi hampir tidak terbatas (Ditjen Informasi dan Komunikasi Publik Kementerian Komunikasi dan Informatika Republik Indonesia, 2018).

Jenis media sosial menurut Kaplan \& Haenlein (2010), terdiri dari

a. Proyek Kolaborasi (Collaborative Projects), jenis ini memungkina pembuatan konten secara bersamasama oleh pengguna akhir seperti wikipedia.

b. Blog, biasa disebut personal website adalah generasi awal dari media sosial yang dapat berisi catatan harian pemilik dan dapat berinteraksi dengan pembaca blog tersebut.

c. Komunitas Konten (Content Communities), tujuan dari pengguna jenis ini adalah untuk saling bertukar 
Jurnal PINUS: Jurnal Penelitian Inovasi Pembelajaran, 7 (1), 2021, Hasan Ashari, Bambang Sancoko

konten menggunakan media sosial, contohnya twitter, Youtube.

d. Situs Jejaring Sosial (Social Networking Sites), adalah aplikasi yang memungkinkan hubungan antar pengguna dengan memuat informasi pribadi bentuk profil, mengundang orang lain untuk dapat mengakses informasi tersebut, mengirim surat elektronik dan pesan cepat ke sesame pengguna. Informasi pribadi ini dapat berbentuk video, file audio, foto dan jurnal pribadi. Contoh dari jenis ini adalah facebook, myspace dan lainlainnya.

e. Virtual Game Worlds, adalah platform yang menghadirkan tampilan tiga dimensi. Pengguna dapat berinteraksi dengan lainnya dalam bentuk avatar yang merupakan personalisasi dari pengguna misalnya mobile legend.

f. Virtual Social Worlds, adalah kelompok kedua dunia maya, yang memungkinkan penghuninya untuk memilih perilakunya sesuai dengan keinginan dan menjalani kehidupan maya sebagaimana kehidupan nyata. Seperti halnya dalam game virtual, sosial virtual tampil dengan avatar dan berinteraksi secara tiga dimensi misalnya second life.

Penggunaan media sosial sudah sangat marak di masyarakat. Lima jenis media sosial terbanyak yang digunakan masyarakat Indonesia, yaitu YouTube, whatsapp, Facebook, Instagram dan twitter. Dari kelima jenis kanal media sosial tersebut empat adalah jejaring sosial sementara satu adalah layanan pesan teks, suara dan video (Hootsuite (We are Social), 2020).

Penggunaan media sosial dapat memberikan manfaat atau juga merugikan, hal ini tergantung kepada tujuan pengguna. Salah satu inovasi tata Kelola pemerintahan yang baik dan responsif adalah dengan penggunaan media sosial sebagai sarana komunikasi. Manfaat manfaat media sosial bagi pemerintah adalah mendorong efisiensi pemerintahan, memulihkan kepercayaan masyarakat yang turun, menghadapi perkembangan jaman dan media komunikasi di saat terjadi situasi bencana alam/kritis (Ditjen Informasi dan Komunikasi Publik Kementerian Komunikasi dan Informatika Republik Indonesia, 2018).

Penggunaan media sosial di dunia pendidikan sudah menjadi kebutuhan. Penggunaan akun-akun media sosial dengan tujuan berbagi informasi baik bersifat administrasi maupun akademik (Marsal \& Hidayati, 2018). Kemudahan akses telekomunikasi dan transportasi harus mampu meningkatkan perkembangan ilmu pengetahuan. Kemudahan ini juga harus diikuti dengan pengembangan sumber daya manusia. Pengembangan sumber daya manusia dilingkungan pemerintah dilaksanakan dengan penyelenggaraan Pendidikan dan pelatihan. Media sosial meningkatkan komunikasi dan interaksi antar peserta diklat serta antara fasilitator dan peserta diklat. Dengan media sosial, fasilitator dan peserta diklat dapat berkomunikasi satu sama lain di dalam atau di luar kelas (Faizi et al., 2013). 


\section{Kompetesi di era digital dan media sosial}

Kebutuhan sumber daya manusia yang memiliki kompetensi dibidang digital sangat diperlukan. Semua pekerjaan pada era digital menggunakan teknologi infromasi. Mengacu pada Digcom 2.0, setidaknya terdapat lima kompetensi digital (European Commission's science and knowledge service, 2015). Kelima kompetensi tersebut adalah:

a. informasi dan Literasi data

1) Menjelajah, mencari dan memfilter data, informasi, serta konten digital

2) Mengevaluasi dan mengelola data, informasi dan konten digital

b. Komunikasi dan kolaborasi

1) Berinteraksi melalui teknologi digital

2) Berbagi data menggunakan teknologi digital

3) Berperan aktif di masyarakat menggunakan layanan digital

4) Berkolaborasi melalui teknologi digital

5) mengetahui etika dan pemahaman penggunaan teknologi digital dan interaksi di komunitas digital

6) Mengelola keamanan identitas digital

c. kemampuan menciptakan konten digital,

1) Mengembangkan konten digital

2) Mengintegrasikan dan reelaborasi kembali konten digital

3) Pemahaman Hak Cipta dan lisensi

4) Melakukan pemrograman

d. Keamanan

1) melindungi terhadap perangkat digital
2) melindungi data dan kerahasiaan,

3) melindungi kesehatan fisik dan psikis pada saat melakukan aktivitas digital

4) melindungi lingkungan/komunitas dan proses belajar.

e. kemampuan mengatasi kendala teknis

1) dapat menyelesaikan kendala teknis

2) identifikasi kebutuhan teknologi yang diperlukan,

3) kreatif dalam menggunakan teknologi digital

4) mampu mengidentifikasi kekurangan/kelemahan teknologi digital.

\section{Penelitian Sebelumnya}

Penelitian yang secara khusus membahas tema widyaiswara masih terbatas. berdasarkan hasil penelusuran penulis, ada beberapa penelitian sebelumnya. Menurut Saputra (2020) widyaiswara harus terbiasa menggunakan internet sebagai media pembelajaran sebagai sarana pembelajaran antara widyaisara dan peserta. Kemampuan yang harus dimiliki widyaiswara antara lain LMS dan materi pembelajran multimedia.

Pesatnya Kemajuan IPTEK mengharuskan peserta pelatihan mampu memanfaatkan teknologi, hal ini juga harus mampu dimiliki oleh widyaiswara(Ratnah, 2020). Widyaiswara sebagai pemeran utama dalam proses Pendidikan dan pelatihan, menjadi tumpuan untuk meberikan produk terbaik dengan menggunakan teknologi (Ratnah, 2020). 
Jurnal PINUS: Jurnal Penelitian Inovasi Pembelajaran, 7 (1), 2021, Hasan Ashari, Bambang Sancoko

\section{METODE PENELITIAN}

Penelitian ini adalah penelitian deskriptif, yaitu penelitian dengan cara mendeskripsikan suatu variabel, dimana tidak dilakukan perbandingan antar variabel, atau menghubungkan antar variabel (Sugiyono, 2010). Penelitian deskriptif bertujuan membuat gambaran tentang suatu kondisi secara obyektif.

Metode yang digunakan dengan studi literatur. Metode ini pada dasarnya rangkaian kegiatan terkait dengan proses pengumpulan data pustaka selanjutnya dibaca, dicatat dan diolah sebagai bahan penelitian (Melfianora, 2019). Pendapat yang sama juga disampaikan oleh (Jamil et al., (2020). Langkah-langkah penelitian dilakukan dengan mengumpulkan literatur berupa artikel, jurnal, buku dan peraturan yang terkait dengan tema. Selanjutnya penulis menguraikan hasil analisa untuk menjawab rumusan masalah penelitian.

\section{PEMBAHASAN}

Perkembangan era digital terjadi disetiap bidang layanan pemerintahan. Sebagai bagian dari pengembangan $e$ government, pengembangan sumber daya manusia di lingkungan pemerintahan juga dilakukan secara elektronik. Hal ini dilakukan sejak tahun 2018 sebagaimana dituangkan dalam Peraturan LAN RI Nomor 8 Tahun 2018 Tentang Pedoman Penyelenggaraan Pengembangan Kompetensi Pegawai Negeri Sipil Melalui E-Learning.

Pengembangan kompetensi secara digital ditindaklanjuti dengan dibangunnya learning management system (LMS) oleh lembaga pelatihan di kementerian/lembaga. Beberapa LMS yang dibangun antara lain:

1. http://klc.kemenkeu.go.id

2. https://lms.pusdiklat.kominfo.go.id

3. https://elearning.menlhk.go.id/

4. http://elearning.kkp.go.id/ dan LMS lainnya yang dibangun oleh kementerian/lembaga.

Berdasarkan Peraturan LAN RI Nomor 8 Tahun 2018, e-Learning adalah pengembangan kompetensi PNS yang dilaksanakan dalam bentuk pelatihan dengan mengoptimalkan penggunaan teknologi informasi dan komunikasi untuk mencapai tujuan pembelajaran dan peningkatan kinerja. Dalam definisi tersebut ditekankan bahwa penggunaan teknologi informasi dan komunikasi menjadi faktor yang menentukan keberhasilan proses pelatihan.

$$
\text { Salah satu tujuan }
$$

penyelenggaraan e-learning adalah memperluas akses bagi PNS dalam mengembangkan kompetensi secara berkesinambungan. Selain LMS, proses pengembangan kompetensi bisa dilakukan melalui media digital yang populer digunakan oleh PNS.

Widyaiswara sebagai salah satu unsur dalam pengembangan kompetensi PNS berbasis elektronik diharuskan memiliki kemampuan untuk menyiapkan kebutuhan disetiap tahap proses pelatihan. Tahap pelatihan tersebut yaitu pelaksanaan dikjartih serta evaluasi dan pengembangan diklat. Kompetensi digital diperlukan oleh widyaiswara untuk menyusun bahan yang akan di gunakan dalam e-learning pada tahap tersebut.

Tren penggunaan media digital harus dipertimbangkan sebagai media 
Jurnal PINUS: Jurnal Penelitian Inovasi Pembelajaran, 7 (1), 2021, Hasan Ashari, Bambang Sancoko

alternatif untuk pengembangan kompetensi PNS. Merujuk dari hasil survey penggunaan media di era digital yaitu media social, maka proses penyampaian pengetahuan dapat dilakukan melalui media sosial yang banyak di akses. Widyaiswara harus memanfaatkan media sosial sebagai alternatif untuk menyampaikan pengetahuan.

\subsection{Kompetensi widyaiswara di era digital}

Tingkat kegunaan media pembelajaran digital bagi pengguna dipengaruhi oleh beberapa faktor. Sebagai bagian dari sistem informasi kualitas media pembelajaran ditentukan oleh beberapa faktor. Menurut Jogiyanto (2007) kualitas sistem informasi ditentukan dua hal yaitu kualitas sistem dan informasi. Dalam kualitas sistem mencakup tingkat Akurasi, isi basis data, tingkat kemudahan penggunaan system, kemudahan untuk dipelajari, dan kesesuaian realisasi kebutuhan pengguna. Sedangkan kualitas informasi mencakup tingkat relevansi, kemampuan dalam memberikan informasi, bentuk, Isi informasi, tingkat akurasi, kekinian, ketepatan waktu, tingkat kegunaan dan kejelasan informasi.

Keberadaan media pembelajaran digital dan medsos di kementerian/lembaga harus dapat diterima oleh pengguna. Kualitas media sebagai bagian dan sistem informasi pembelajaran harus dikelola dengan baik oleh tim yang kompeten. Berbagai kompetensi diperlukan baik yang terkait teknis maupun subtansi. Kempat kompetensi widyaisawara (pengelolaan pembelajaran, kepribadian, sosial dan substantif) adalah bagian yang sangat penting dalam proses pembelajaran di era digital dan media sosial. Namun keempat kompetensi harus disesuaikan dengan kebutuhan pembelajaran di era digital.

Widyaisawara

dalam

melaksanakan tugas sangat terkait dengan kualitas informasi sebagaimana pendapat Jogiyanto. Hal ini dilakukan di setiap tahap pelaksanaan tugas seperti evaluasi dan pengembangan diklat, pelaksanaan dikjartih dan pengembangan profesi. Kurikulum pelatihan, modul, GBPP/SAP, bahan tayang, bahan ajar, proses tatap muka baik klasikal maupun daring, soal yang digunakan evaluasi pelatihan disusun berbasis teknologi digital. Bahan-bahan pembelajaran harus bisa memenuhi kebutuhan belajar dimana saja dan kapan saja. Peran widyaiswara harus ada mulai dari perencanaan, pembuatan konten dan evaluasi untuk memastikan tujuan pembelajaran tercapai.

a. informasi dan Literasi data

widyaiswara dalam menyusun kurikulum, modul, GBPP/SAP, bahan tayang, bahan ajar, serta evaluasi pembelajaran memerlukan data dan informasi yang memadai. Hal ini yang dikenal dengan istilah literasi digital. Literasi Digital adalah proses penggunaan alat dan fasilitas digital yang didasarkan kesadaran, sikap, dan kemampuan individu yang digunakan untuk identifikasi, akses, mengelola, integrasi, evaluasi, analisis, sintesis segala sumber daya digital, membangun pengetahuan baru, menciptakan ekspresi media, dan membangun komunikasi 
Jurnal PINUS: Jurnal Penelitian Inovasi Pembelajaran, 7 (1), 2021, Hasan Ashari, Bambang Sancoko

dengan orang lain dalam konteks situasi kehidupan tertentu dalam rangka tindakan sosial yang konstruktif (Martin \& Grudziecki, 2006).

Untuk bisa memenuhi kebutuhan kompetensi ini, widyaiswara bisa mendapatkan dengan cara digital dengan mudah dan hemat. Kebutuhan sumber literatur bisa di peroleh dengan menjadi anggota perpustakaan nasional secara online. Fasilitas yang diperoleh adalah akses ke jurnal-jurnal secara gratis. Kebutuhan data sekunder bisa diperoleh diberbagai lembaga baik pemerintah maupun non pemerintah misalnya BPS.

b. Komunikasi dan kolaborasi

Widyaiswara dalam berinteraksi di era digital berbeda dengan era sebelumnya. Proses pekerjaan dilaksanakan secara digital, mulai dari rapat, diskusi, kegiatan belajar mengajar sampai dengan evaluasi pembelajaran. Widyaiswara harus mampu berkomunikasi baik berbentuk tulisan melalui aplikasi pesan maupun audio visual melalui aplikasi yang mendukung percakapan dengan banyak pengguna. Kolaburasi dengan orang lain diperlukan untuk menghasilkan output yang baik, kemamuan berbagi data melalui teknologi digital baik melalui email maupun media penyimpanan online. Dalam komunikasi, widyaiswara harus mengetahu norma dan etika komuniasi di era digital dan media sosial. Kesalahan komunikasi akan merugikan tidak hanya pribadi widyaiswara akan tetapi institusi kementerian/lembaga juga akan dirugikan. Untuk itu widyaiswara harus mampu mengelola keamanan identitas digital seperti akun dan password. c. kemampuan menciptakan konten digital,

Konten digital menentukan kualitas pembelajaran di era digital. Konten digital dapat dipergunakan untuk kebutuhan organisasi dan juga individu. Untuk kebutuhan organisasi, widyaiswara harus ikut berkolaburasi dalam tim pengembangan konten digital. Tugas yang paling mendasar adalah menyiapkan substansi pembelajaran sesuai dengan keahlian. Peran minimal yang haru dilakukan widyaiswara adalah melakukan supervisi terhadap substansi materi mulai dari tahap perencanaan, produksi, editing sampai publikasi.

Untuk kebutuhan individu, widyaiswara bisa membuat channel, forum, grup, blog dan lain-lain yang dikelola secara personal. Widyaiswara dapat membentuk tim atau dikerjakan sendiri dalam pembuatan konten. Konten dapat diproduksi dengan aplikasi yang telah digunakan sebelumnya dengan aplikasi tambahan yang bisa didapatkan secara gratis di internet. Diantara aplikasi yang bisa digunakan untuk pembuatan konten berupa video yaitu powerpoint dan camtasia. Dengan aplikasi yang sudah biasa dipergunakan tentu tidak menyulitkan untuk membuat konten yang menarik.

Dalam proses produksi konten digital hal yang sangat penting diperhatikan adalah pemahaman Hak Cipta dan lisensi. Widyaiswara harus mempelajari dengan detil batasan penggunaan hasil karya orang lain agar tidak melanggar hak cipta dan lisensi. Pelanggaran atas hak cipta dan lisensi dapat berakibat tuntutan hukum. 
Jurnal PINUS: Jurnal Penelitian Inovasi Pembelajaran, 7 (1), 2021, Hasan Ashari, Bambang Sancoko

\section{d. Keamanan}

Dalam bekerja, widyaiswara menggunakan alat pengolah data berupa handphone, notebook, komputer dan sebagainya baik milik pribadi maupun barang milik negara. Dalam penggunaanya harus memperhatikan aspek keamanan baik hardware maupun software. Penipuan dengan modus pembajakan nomor HP yang digunakan di media sosial, akun media sosial dan sebagainya perlu menjadi perhatian. Widyaiswara harus mempunya kompetensi untuk menjaga keamanan peralatan kerjanya. Penggunaan password dan PIN haru dilakukan secara bijak. Hal ini penting terkait dengan jenis data-data yang disimpan di perangkat digital. Terkait dengan kompetensi ini, widyaisawara juga harus melindungi lingkungan/proses belajar dari hal-hal yang mengganggu, misalnya tingkat kebisingan.

e. kemampuan memecahkan dan mengatasi persoalan secara teknis

Kendala-kendala

dalam

penggunaan perangkat digital harus diantisipasi. Permasalahan lupa password, laptop tiba-tiba mati, LCD yang bermasalah, suara yang tidak terdengar dan sebagainya kadang terjadi pada saat widyaiswara bekerja. Widyaiswara harus mampu menyelesaikan permasalahn yang dasar pada perangkat digital yang dipergunakan.

Bagaimana cara memenuhi kompetensi tersebut? Jika ada kesempatan belajar secara formal maka ini adalah cara ideal. Sesuai dengan tema paper ini, selain belajar secara formal dalam pelatihan, kompetensi digital tersebut dapat dipelajari secara digital diberbagai sumber yang sudah tersedia secara otodidak.

\subsection{Jenis Media Sosial sebagai media pembelajaran}

Jenis media digital/sosial yang semakin banyak diera digital menjadi peluang untuk dapat mempercepat proses pembelajaran. Penggunaan media digital/sosial harus memperhatikan tingkat efektivitas dan efisiensi. Widyaiswara harus mampu memilih media yang tepat.

Website adalah media wajib bagi organisasi untuk komunikasi dengan para pemangku kepentingan. Selain itu, penggunaan media sosial yang tepat akan membantu proses distribusi informasi. Alternatif media yang menduduki rangking lima besar adalah YouTube, whatsapp, Facebook, Instagram dan twitter (Hootsuite (We are Social), 2020). Badan Pendidikan dan Pelatihan Keuangan memiliki akun facebook bppk.kemenkeu, twitter @bppkkemenkeu, instagram @bppkkemenkeu dan youtube di channel "BPPK Kemenkeu RI". Selain akun media sosial, penggunaan media pesan instan whatsapp menjadi pilihan dalam menyampaikan pesan yang berisi informasi formal organisasi baik internal maupun eksternal.

Secara organisasi, widyaisara adalah bagian dari tim yang mempersiapkan kebutuhan di media digital/sosial. Hal ini dapat dilakukan secara maksimal jika widyaisawara memiliki komptensi digital. 
Jurnal PINUS: Jurnal Penelitian Inovasi Pembelajaran, 7 (1), 2021, Hasan Ashari, Bambang Sancoko

Secara personal, widyaiswara juga dapat berkontribusi dalam proses pembelajaran dengan membuat akun dan channel pribadi. Kompetensi menciptakan konten yang dimiliki widyaiswara dapat dipergunakan untuk memproduksi konten di akun dan channel pribadi.

Akun dan channel pribadi hendaknya mengikuti kebijakan yang dibuat oleh organisasi. Hal ini untuk menghindari adanya konten yang merugikan organisasi. Organisasi dapat membuat pedoman/petunjuk pengelolaan akun atau channel media sosial tidak hanya untuk widyaisawara tetapi juga untuk semua pegawai. Kebebasan ekspresi pegawai perlu diatur dengan tujuan menjaga tindakan-tindakan yang merugikan. Pengaturan ini bukan dalam rangka pengekangan, akan tetapi memberikan rambu yang jelas terkait dengan kebebasan penyampaian ide kreatif pegawai.

Di era digital berita dan informasi bisa saja tidak dapat dipertanggungjawabkan, dengan semakin banyak akun dan channel media sosial widyaiswara diharapkan bisa memberikan informasi yang seimbang dan bertanggung jawab. Berbagi tips, pengalaman dan aktivitas keseharian adalah konten yang menarik untuk dijadikan sumber inspirasi. Bagi widyaiswara, minimal menggunakan satu jenis media sosial sebagai sarana untuk berbagi.

Untuk

pengembangan

kompetensi widyaisawara, berbagai jenis tersedia diberbagai media pembelajaran. Di era digital tidak ada lagi alasan keterbatasan dalam pengembangan diri.
Pelatihan formal, forum, langganan materi pembelajaran secara berkala dan masih banyak lagi cara untuk mengembangkan kompetensi.

\subsection{Kolaburasi Knowlegde Management System dengan Media Sosial}

Keterbukaan di era digital menuntut adanya perluasan jaringan sebagai sarana untuk menyebarkan berbagai konten pembelajaran. Media digital pemerintah tidak dapat berdiri sendiri. Kolaburasi antara media digital dengan berbagai media digital lainnya menjadi keharusan. Hal ini telah dilakukan semua kementerian/lembaga yang menggunakan media digital/sosial untuk mengkomunikasikan konten yang dimiliki. Lembaga pendidikan pemerintah juga demikian, sebagaimana penulis paparkan, BPPK adalah salah satu contoh.

Pada sub bahasan ini, dalam konteks kolaburasi, penulis fokus pada aspek efisiensi sumber daya. Dengan meanfaatkan media sosial, konten pembelajaran dapat di tempatkan di media sosial, misalnya youtube jika berbentuk video. Dengan cara ini, akan terjadi penghematan media penyimpanan di LMS. Organisasi dapat membuat kriteria konten yang sifatnya terbuka. Sedangkan untuk konten yang sifatnya tertutup tetap disimpan di media penyimpanan LMS.

Sebagai contoh, hasil knowledge capture (KC) widyaiswara di Badan Pendidikan dan Pelatihan Keuangan. Widyaiswara Pusdiklat Anggaran dan Perbendaharaan setiap tahun mempunya 
Jurnal PINUS: Jurnal Penelitian Inovasi Pembelajaran, 7 (1), 2021, Hasan Ashari, Bambang Sancoko

IKU untuk menghasilan $\mathrm{KC}$ berbentuk video berjumlah empat video. Secara umum rata-rata besar file video $50 \mathrm{MB}$. Jika ada 25 widyaiswara makan dalam satu tahun dihasilkan seratus video. Dengan besar file $50 \mathrm{MB}$, maka seratus video membutuhkan media penyimpanan 5 GB. Jika video $\mathrm{KC}$ widyaiswara di unggah ke media sosial misalnya Youtube tentu akan mengurangi beban media penyimpanan server LMS.

Berdasarkan hasil penulusuran penulis dari laman https://socialblade.com/youtube/channel/ UCDBqV8WfMOK2pwHQZvONb7g, channel BPPK RI telah terunggah sebanyak 941 video. Dengan menggunakan media sosial, penggunaan media penyimpanan di server LMS akan lebih efisien. Di LMS perlu dibuat link video yang mengarah ke media sosial disertai dengan deskripsi video.

Untuk video konten pribadi widyaiswara juga dapat di buat link di LMS. Hal ini untuk mengapresiasi widyaiswara yang telah berkontribusi dalam penggunaan media digital/sosial sebagai sarana pembelajaran. Konten pribadi yang dimaksud adalah konten yang terkait dengan materi pembelajaran.

Penggunaan media sosial oleh lembaga pemerintah juga dapat dijadikan sebagai alternatif sumber penerimaan negara. Di beberapa media sosial dimungkinkan adanya kompensasi kepada pengisi konten. Namun hal ini harus mempertimbangkan peraturan perundang-undangan. Sebagai contoh, channel media sosial youtbe BPPK berdasarkan laman socialblade.com yang penulis akses 14 Maret 2021, berpotensi mendapatkan penghasilan bulanan 25 sampai dengan 399 US Dollar. ( https://socialblade.com/youtube/channel/ UCDBqV8WfMOK2pwHQZvONb7g)

Penggunaan media komunikasi digital baik berbasis teks, audio, audio visual hendaknya diupayakan yang memberikan kontribusi pada penerimaan negara terutama di bidang perpajakan. Kolaburasi dengan BUMN bidang telekomunikasi untuk menyediakan layanan komunikasi daring sangat diperlukan. Media komunikasi diutamakan menggunakan produk seperti umeetme.id. Penulis tidak bermaksud mendiskreditkan produk tertentu, tetapi penggunaan sumber daya dari dalam negeri pasti akan lebih memberikan manfaat finansial yang lebih bagi keuangan negara.

\subsection{Widyaiswara Agile}

Konsep widyaiswara agile mengacu pada konsep Learning Agility Dr. W. Warner Burke. Di era digital dibutuhkan agility dalam banyak bidang termasuk pembelajaran. Menurut Dr. W. Warner Burke dalam Hakim (2019) ada sembilan dimensi dalam Learning Agility yang dapat dieksplorasi dan dibangun dalam diri seseorang, yaitu:

a. Fleksibilitas yaitu individu yang mau membuka diri untuk gagasan dan kondis baru serta dapat memecahkan masalah dengan solusi baru.

b. Kecepatan yaitu cepat mewujudkan gagasan yang dapat memberikan alternatif-alternatif baru lainnya

c. Experimenting yaitu berusaha menerapkan aktivitas baru, gagasan, alternatif yang bertujuan menemukan 
Jurnal PINUS: Jurnal Penelitian Inovasi Pembelajaran, 7 (1), 2021, Hasan Ashari, Bambang Sancoko

alternatif aktivitas yang paling efektif.

d. Berani mengambil risiko yaitu mempunyai keberanian mencoba melakukan aktifitas-aktifitas baru untuk mendapatkan peluang dan tantangan baru.

e. Berani mengambil risiko Interpersonal yaitu berani berbeda pendapat degan orang dan berdiskusi dalam rangka proses pembelajaran dan perubahan.

f. Kolaburasi yaitu kemampuan bekerja sama dalam rangka penemuan cara baru sehingga terjadi proses pembelajaran.

g. Pengumpulan informasi yaitu kemampuan untuk selalu update terhadap informasi dengan menggunakan metode pengumpulan yang terkini.

h. Mencari Umpan Balik yaitu upaya mendapatkan umpan balik terkait mengenai ide dan kinerja.

i. Refleksi yaitu melakukan evaluasi kinerja untuk cara yang lebih efektif dalam bekerja.

Widyaiswara akan mampu tetap eksis di tengah dunia digital dan media sosial yang terus berkembang apabila dapat memenuhi sembilan dimensi tersebut.

\section{KESIMPULAN}

Berdasarkan uraian pada bab sebelumnya kesimpulan dari paper ini adalah:

1. Kompetensi yang dibutuhkan widyaiswara unutk menghadapi perkembangan di dunia digital dan media sosial tidak cukup hanya empat kompetensi standar. Kompetensi digital diperlukan sebagai syarat untuk tetap eksis. Kompetensi digital tersebut adalah "informasi dan Literasi data; Komunikasi dan kolaborasi; kemampuan menciptakan konten digital; Keamanan dan kemampuan memecahkan dan mengatasi persoalan secara teknis".

2. Website adalah media yang wajib dibangun oleh organisasi pemerintah untuk komunikasi dengan para pemangku kepentingan. Sarana lain untuk pengembangan kompetesi dapat menggunakan YouTube, whatsapp, Facebook, Instagram dan twitter yang merupakan lima platform media social ranking tertinggi. Penggunaan media sosial tidak hanya menggunakan akun institusi tetapi setiap widyaiswara haru memiliki akun minimal di satu jenis media sosial. Media sosial widyaiswara digunakan untuk berbagi konten tentang tips, pengalaman, dan aktivitas personal yang sifatnya mengedukasi publik. Dalam penggunaan media sosial harus selalu menggunakan norma dan etika sebagai ASN.

3. Kolaburasi KMS dengan media sosial menjadi keharusan. Kolaburasi dapat bermanfaat untuk kedua belah pihak. Secara khusus bagi KMS lembaga pelatihan pemerintah, penggunaan media sosial dapat mengurangi penggunaan sumberdaya yang diperlukan dalam komunikasi digital. Selain itu penggunaan media sosial dapat dijadikan alternatif sumber penerimaan negara sesuai dengan peraturan perundangan. 
Jurnal PINUS: Jurnal Penelitian Inovasi Pembelajaran, 7 (1), 2021, Hasan Ashari, Bambang Sancoko

4. Eksistensi widyaiswara di dunia digital dan media sosial akan dapat dilakukan dengan membentuk widyaiswara dengan sifat agile.

Untuk menindaklanjuti paper ini, penulis memberikan rekomendasi sebagai berikut:

1. Widyaiswara diwajibkan melakukan pengembangan kompetensi yang terkait dengan perkembangan di era digital dan media sosial.

2. Widyaisawara diwajibkan untuk mempunyai akun di salah satu media sosial dan mengisi dengan konten yang bermanfaat untuk pengembangan kompetensi pengguna layanan pelatihan.

3. Dirumuskan pedoman/petunjuk pengelolaan akun media sosial bagi widyaiswara yang disenergikan dengan akun media sosial organisasi dan LMS.

4. Dirumuskan kode etik dan norma dalam penggunaan media sosial dan komunikasi digital.

5. Dilakukan pengkajian terhadap potensi penerimaan negara dalam penggunaan akun di media sosial.

\section{DAFTAR RUJUKAN}

Anwar, R. K., \& Rusmana, A. (2017). Komunikasi Digital Berbentuk Media Sosial dalam Meningkatkan Kompetensi bagi Kepala, Pustakawan, dan Tenaga Pengelola Perpustakaan. Jurnal Aplikasi Ipteks Untuk Masyarakat, 6(3).

Asosiasi Penyelenggara Jasa Internet Indonesia. (2020). Laporan Survei Internet APJII 2019-2020 (Q2).
Ditjen Informasi Dan Komunikasi Publik Kementerian Komunikasi Dan Informatika Republik Indonesia. (2018). Memaksimalkan Penggunaan Media Sosial Dalam Lembaga Pemerintah. Ditjenl Informasi Dan Komunikasi Publik Kementerian Komunikasi Dan Informatika Republik Indonesia.

European Commission's science and knowledge service. (2015). The Digital Competence Framework 2.0.

https://ec.europa.eu/jrc/en/digco mp/digital-competenceframework.

Faizi, R., El Afia, A., \& Chiheb, R. (2013). Exploring the Potential Benefits of Using Social Media in Education. International Journal of Engineering Pedagogy (IJEP), 3(4).

https://doi.org/10.3991/ijep.v3i4. 2836.

Fauziah, N. M., \& Prasetyo, A. W. (2019). ASN Corporate University: Sebuah Konsep Pendidikan dan Pelatihan Pada Era Disruptif. Civil Service, 13(2).

Hakim, L. N. (2019). Learning Agility; Skill yang Wajib Dimiliki di Tengah Ketidakpastian Karir. https://haihc.com/learningagility-skill-yang-wajib-dimilikidi-tengah-ketidakpastian-karir/.

Hermawansyah, A., \& Pratama, A. R. (2021). Analisis Profil dan Karakteristik Pengguna Media Sosial di Indonesia dengan 
Jurnal PINUS: Jurnal Penelitian Inovasi Pembelajaran, 7 (1), 2021, Hasan Ashari, Bambang Sancoko

Metode EFA dan MCA. Techno.COM, 20(1), 69-82.

Hootsuite (We are Social). (2020). Indonesian Digital Report 2020.

Indrajit, R. E. (2006). Electronic government: strategi pembangunan dan pengembangan sistem pelayanan publik berbasis teknologi digital (3rd ed.). Andi.

Isagah, T., \& Wimmer, M. A. (2017). Mobile government applications: Challenges and needs for a comprehensive design approach. ACM International Conference Proceeding Series, Part F128003. https://doi.org/10.1145/3047273. $\underline{3047305 .}$.

Jamil, F., Mukhaiyar, R., \& Husnaini, I. (2020). Kajian Literatur Rekonstruksi Mata Kuliah(Studi Kasus Mata Kuliah Pengolahan Sinyal Teknik Elektro UNP). JTEV (JURNAL TEKNIK ELEKTRO DANVOKASIONAL), 6(2), 198-203.

Jogiyanto. (2007). Model Kesuksesan Sistem Teknologi Informasi. Andi.

Kaplan, A. M., \& Haenlein, M. (2010). Users of the world, unite! The challenges and opportunities of Social Media. Business Horizons, 53(1), 59-68. https://doi.org/10.1016/j.bushor.2 $\underline{009.09 .003 .}$.

Kompas. (2021). Jokowi Minta agar Tol Langit Palapa Ring Tersambung hingga Rumah Warga. https://nasional.kompas.com/read /2021/02/26/11013641/jokowi- minta-agar-tol-langit-palapa-ringtersambung-hingga-rumahwarga?page $=$ all.

Marsal, A., \& Hidayati, F. (2018). Pengaruh Penggunaan Media Sosial Terhadap Kinerja Pegawai Di Lingkungan UIN Suska Riau. Jurnal Ilmiah Rekayasa Dan Manajemen Sistem Informasi, 4(1).

Martin, A., \& Grudziecki, J. (2006). DigEuLit: Concepts and Tools for Digital Literacy Development. Innovation in Teaching and Learning in Information and Computer Sciences, 5(4). https://doi.org/10.11120/ital.2006 .05040249 .

Melfianora. (2019). KTI dengan Studi Literatur. Https://Osf.Io/Gfe9w/. https://osf.io/gfe9w/

Melissa, E. (2010). Budaya Digital Dan Perubahan Konsumsi Media Masyarakat.

Morrar, R., \& Arman, H. (2017). The Fourth Industrial Revolution (Industry 4.0): A Social Innovation Perspective. Technology Innovation Management Review, 7(11). https://doi.org/10.22215/timrevie w/1117.

Ratnah. (2020). Challenges and Opportunities Widyaiswara in Dealing with the COVID-19 Plague Through ELearning. Jurnal Bestari, 1(1), 22-31.

Rokhman, A. (2011). E-Government Adoption in Developing Countries; the Case of Indonesia. 
Jurnal PINUS: Jurnal Penelitian Inovasi Pembelajaran, 7 (1), 2021, Hasan Ashari, Bambang Sancoko

Journal of Emerging Trends in Computing and Information Sciences, 2(5).

Saputra, U. N. (2020). Tantangan Widyaiswara di Era Industri 4.0. Jurnal Lingkar Widyaiswara, 7(1), 23-29.

Schwab, K. (2016). The Fourth Industrial Revolution: what it means, how to respond.

https://www.weforum.org/agenda /2016/01/the-fourth-industrialrevolution-what-it-means-andhow-to-respond/.

Sugiyono. (2010). Metode Penelitian Pendidikan Pendekatan Kuantitatif, Kualitatif, dan $R \& D$. CV Alvabeta.

Vaidya, S., Ambad, P., \& Bhosle, S. (2018). Industry 4.0 - A Glimpse. Procedia Manufacturing, 20, 233-238.

https://doi.org/10.1016/j.promfg. 2018.02.034.

\section{PERATURAN}

Keputusan Menteri Keuangan No. 924/KMK.011/2018 Tentang Kementerian Keuangan Corporate University.

Peraturan Bersama Kepala LAN Dan Kepala BKN Nomor 1 Tahun 2015 dan Nomor 8 Tahun 2015 tentang Ketentuan Pelaksanaan Peraturan Menteri Pendayagunaan Aparatur Negara Dan Reformasi Birokrasi RI Nomor 22 tahun 2014 Tentang Jabatan Fungsional Widyaiswara Dan Angka Kreditnya.
Peraturan Menteri PAN-RB No 22 tahun 2014 Tentang Jabatan Fungsional.

Perkalan No. 5 Tahun 2008 Tentang Standar Kompetensi Widyaiswara.

Peraturan Menteri Keuangan No.226/PMK.011/2019 tentang Manajemen Pengetahuan Di Lingkungan Kementerian Keuangan.

Peraturan LAN RI No. 8 Tahun 2018 Tentang Pedoman Penyelenggaraan Pengembangan Kompetensi Pegawai Negeri Sipil Melalui E-Learning. 